\title{
Fyn Kinase Induces Synaptic and Cognitive Impairments in a Transgenic Mouse Model of Alzheimer's Disease
}

\author{
Jeannie Chin, ${ }^{1,2}$ Jorge J. Palop, ${ }^{1,2}$ Jukka Puoliväli, ${ }^{1,2}$ Catherine Massaro, ${ }^{1,3}$ Nga Bien-Ly, ${ }^{1}$ Hilary Gerstein, ${ }^{1}$ \\ Kimberly Scearce-Levie, ${ }^{1}$ Eliezer Masliah ${ }^{4}$ and Lennart Mucke ${ }^{1,2,3}$ \\ ${ }^{1}$ Gladstone Institute of Neurological Disease, ${ }^{2}$ Department of Neurology, and ${ }^{3}$ Neuroscience Graduate Program, University of California, San Francisco, San \\ Francisco, California 94158, and ${ }^{4}$ Departments of Neurosciences and Pathology, University of California at San Diego, La Jolla, California 92093
}

\begin{abstract}
Human amyloid precursor protein (hAPP) transgenic mice with high levels of amyloid- $\beta$ (A $\beta$ ) develop behavioral deficits that correlate with the depletion of synaptic activity-related proteins in the dentate gyrus. The tyrosine kinase Fyn is altered in Alzheimer's disease brains and modulates premature mortality and synaptotoxicity in hAPP mice. To determine whether Fyn also modulates A $\beta$-induced behavioral deficits and depletions of synaptic activity-dependent proteins, we overexpressed Fyn in neurons of hAPP mice with moderate levels of $\mathrm{A} \beta$ production. Compared with nontransgenic controls and singly transgenic mice expressing hAPP or FYN alone, doubly transgenic FYN/hAPP mice had striking depletions of calbindin, Fos, and phosphorylated ERK (extracellular signal-regulated kinase), impaired neuronal induction of Arc, and impaired spatial memory retention. These deficits were qualitatively and quantitatively similar to those otherwise seen only in hAPP mice with higher A $\beta$ levels. Surprisingly, levels of active Fyn were lower in high expresser hAPP mice than in NTG controls and lower in FYN/hAPP mice than in FYN mice. Suppression of Fyn activity may result from dephosphorylation by striatal-enriched phosphatase, which was upregulated in FYN/hAPP mice and in hAPP mice with high levels of A $\beta$. Thus, increased Fyn expression is sufficient to trigger prominent neuronal deficits in the context of even relatively moderate $A \beta$ levels, and inhibition of Fyn activity may help counteract $\mathrm{A} \beta$-induced impairments.
\end{abstract}

Key words: hippocampus; plasticity; amyloid $\beta$; Arc; spatial memory; striatal-enriched phosphatase (STEP)

\section{Introduction}

The amyloid precursor protein (APP) is expressed at high levels in synapses in which it appears to play roles in synaptic plasticity and neurite outgrowth (Turner et al., 2003). APP undergoes proteolytic cleavage resulting in several metabolites, including amyloid- $\beta$ (A $\beta$ ) peptides (Turner et al., 2003). Abnormal accumulation and deposition of $A \beta$ are pathological hallmarks of Alzheimer's disease (AD), which is associated with progressive cognitive decline and degeneration of synapses and neurons. However, the precise relationship between $\mathrm{A} \beta$, synaptic impairments, and cognitive decline remains uncertain (Walsh and Selkoe, 2004).

APP/A $\beta$-induced neuronal and behavioral deficits have been investigated in several transgenic (TG) mouse models (Higgins and Jacobsen, 2003; Gotz et al., 2004; Kobayashi and Chen, 2005). Findings from many of these models, as well as from in vitro studies, are consistent with the hypothesis that small nonfibrillar assemblies of $\mathrm{A} \beta$ can aberrantly engage intracellular signaling

\footnotetext{
Received July 19, 2005; revised Aug. 30, 2005; accepted Sept. 3, 2005.

This work was supported by fellowships from the John Douglas French Alzheimer's Foundation (J.C.) and the Academy of Finland (J.P.) and by National Institutes of Health Grants NS41787 and AG022074 (L.M.). We thank N. Kojima for Fyn transgenic mice; P. Worley for the anti-Arc antibody; G.-Q. Yu, X. Wang, and H. Ordanza for technica assistance; and D. Murray McPherson for administrative assistance.

Correspondence should be addressed to Dr. Lennart Mucke, Gladstone Institute of Neurological Disease, 1650 Owens Street, San Francisco, CA 94158. E-mail: Imucke@gladstone.ucsf.edu.

J. Puoliväli's present address: Cerebricon Ltd., Microkatu 1, P.0. Box 1188, 70211 Kuopio, Finland.

DOI:10.1523/JNEUROSCI.2980-05.2005

Copyright $\odot 2005$ Society for Neuroscience $\quad 0270-6474 / 05 / 259694-10 \$ 15.00 / 0$
}

pathways in neurons and thereby disrupt normal synaptic function (Lambert et al., 1998; Hsia et al., 1999; Klein et al., 2001; Verdier and Penke, 2004; Walsh and Selkoe, 2004). Several cellsurface receptors have been identified that might mediate these $\mathrm{A} \beta$ effects, including integrins (Sabo et al., 1995; Bi et al., 2002; Grace et al., 2002), nicotinic acetylcholine receptors (nAChRs) (Dineley et al., 2001), the p75 neurotrophin receptor (Yaar et al., 1997), and the receptor for advanced glycation end products (Yan et al., 1996; Arancio et al., 2004). Many of these receptors are located at the postsynaptic membrane, providing $\mathrm{A} \beta$ with a suitable vantage point from which to disrupt synaptic function.

Several signaling molecules that transduce receptor-activated signals are localized beneath the postsynaptic membrane and modulate cell-cell adhesion, receptor clustering, or the scaffolding of signaling molecules (Kennedy, 1997). One of these molecules is Fyn, a member of the Src family of tyrosine kinases (Thomas and Brugge, 1997). Strategically located at the postsynaptic density of glutamatergic synapses, it is in an excellent position to modulate the effects of $A \beta$ on synapses. Indeed, Fyn activation occurs during engagement of integrins and glutamate receptors (Roskoski, 2004; Salter and Kalia, 2004), both of which have been implicated in $\mathrm{A} \beta$-induced disruption of synaptic function (Klein et al., 2001; Grace et al., 2002; Williamson et al., 2002). Furthermore, the distribution and levels of Fyn are altered in AD brains (Shirazi and Wood, 1993; Ho et al., 2004), and the toxic effects of $\mathrm{A} \beta$-derived diffusible ligands on murine hippocampal slices were blocked by the genetic ablation of Fyn (Lambert et al., 
A
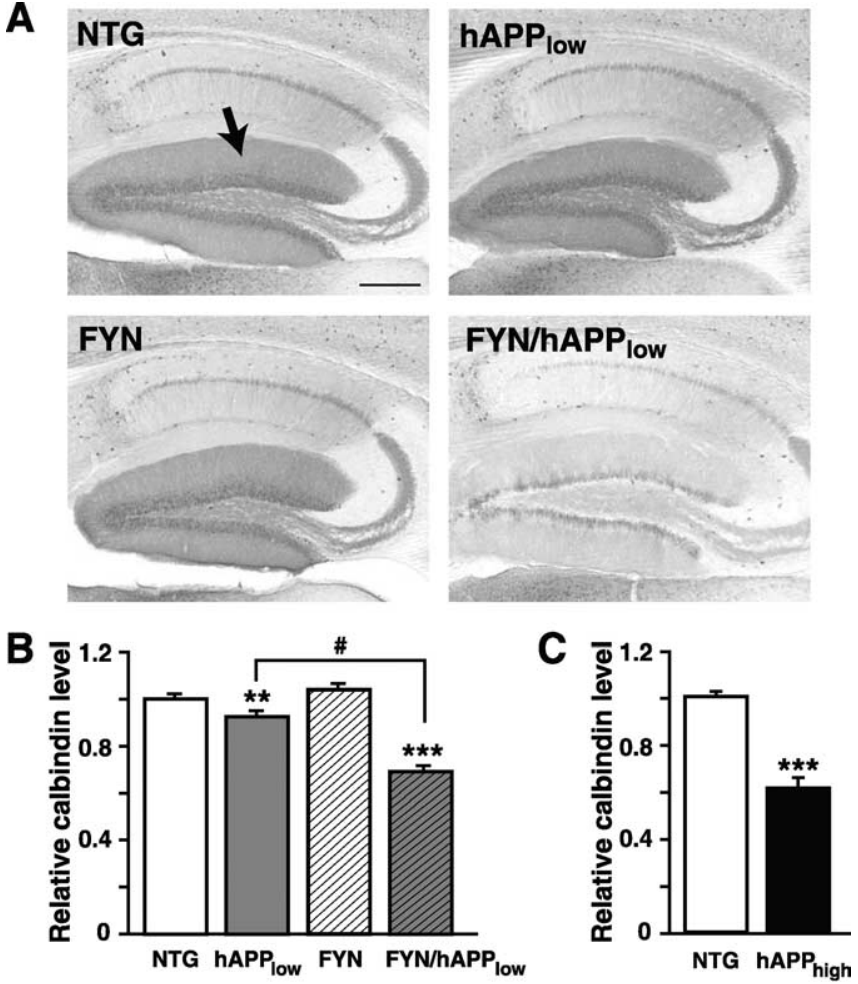

D

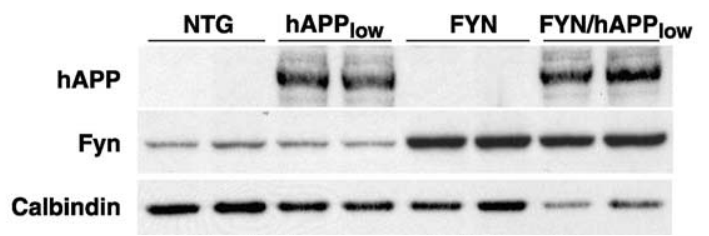

Figure 1. Increased expression of Fyn triggers $\mathrm{hAPP} / \mathrm{A} \beta$-induced depletion of calbindin in the dentate gyrus. $A$, Immunostaining for calbindin in the molecular layer of the dentate gyrus (arrow) demonstrates marked depletion in a severely affected FYN/hAPP ${ }_{\text {low }}$ mouse compared with NTG and singly TG mice. $B, C$, Quantitation of relative calbindin immunoreactivity (IR) levels in the molecular layer of the dentate gyrus in 23-37 mice per genotype $(\boldsymbol{B})$ and 9 mice per genotype ( $\boldsymbol{C}$. The interaction between hAPP low and FYN was significant by ANOVA ( $p<$ $0.001) .{ }^{* *} p<0.01,{ }^{* * *} p<0.001$ versus NTG; ${ }^{*} p<0.05$. D. Western blot analysis of dentate gyrus lysates demonstrates comparable levels of hAPP (top) and Fyn (middle) overexpression in singly TG and FYN/hAPP low mice, as well as calbindin reductions in FYN/hAPP ${ }_{\text {low }}$ mice (bottom). Scale bar, $250 \mu \mathrm{m}$.

1998). Finally, ablation of Fyn decreased, whereas overexpression of Fyn increased, $A \beta$-induced synaptotoxicity and premature mortality in human APP (hAPP) mice (Chin et al., 2004). Together, these results suggest that $\mathrm{A} \beta$ may derange synaptic functions by aberrantly engaging Fyn-related signaling pathways.

Here, we tested the hypothesis that increased neuronal activity of Fyn can trigger and exacerbate $A \beta$-induced neuronal and behavioral deficits. Increasing Fyn activity in neurons elicited memory impairments in TG mice with moderate levels of hAPP/A $\beta$ expression and significantly exacerbated their depletion of synaptic activity-related proteins, creating a striking phenocopy of functional and molecular impairments typically seen only in mice with much higher levels of $A \beta$. These results highlight the potential significance of pathogenic interactions between hAPP/A $\beta$ and Fyn-related signaling pathways.

\section{Materials and Methods}

TG mice. hAPP TG lines J9 and J20 produce hAPP carrying the Swedish (K670N, M671L) and Indiana (V717F) familial AD mutations (hAPP770 numbering) directed by the platelet-derived growth factor (PDGF) $\beta$ chain promoter (Rockenstein et al., 1995; Mucke et al., 2000). The lines were crossed for $>10$ generations onto a C57BL/6 background using NTG mice from The Jackson Laboratory (Bar Harbor, ME). Heterozygous FYN TG mice (line N8) overexpress wild-type mouse Fyn directed by the calcium/calmodulin-dependent protein kinase II $\alpha$ promoter on a C57BL/6 background (Kojima et al., 1997, 1998). Unless indicated otherwise, mice were evaluated at $6-8$ months of age. To decrease variability, only male mice were assessed in the Morris water maze; all other measurements were performed on gender-balanced groups. Mice were anesthetized and flush-perfused transcardially with PBS. Hemibrains were fixed in $4 \%$ phosphate-buffered paraformaldehyde or stored at $-70^{\circ} \mathrm{C}$. All experiments were approved by the Committee on Animal Research of the University of California, San Francisco.

Immunohistochemistry. Sliding microtome sections $(30 \mu \mathrm{m})$ were avidin-biotin/immunoperoxidase stained using the following primary antibodies: anti-calbindin (1:15,000; rabbit polyclonal; Swant, Bellinzona, Switzerland), anti-Fos (1:10,000; rabbit polyclonal Ab-5; Oncogene, San Diego, CA), anti-dually phosphorylated extracellular signal-regulated kinase 1/2 (phospho-ERK1/2; 1:100; rabbit polyclonal; Cell Signaling, Beverly, MA), anti-Arc (1:8000; rabbit polyclonal; a gift from Dr. P. Worley, Johns Hopkins University, Baltimore, MD), and biotinylated anti-A $\beta$ (1:500; mouse monoclonal 3D6; Elan Pharmaceuticals, South San Francisco, CA). Biotinylated goat anti-rabbit (1:200; Vector Laboratories, Burlingame, CA) was used as the secondary antibody. Diaminobenzidine was used as a chromagen. For the analysis of calbindin-immunoreactive (IR) structures, two coronal sections ( $300 \mu \mathrm{m}$ apart) per mouse between -2.54 and $-2.80 \mathrm{~mm}$ from bregma were selected. The integrated optical density (IOD) of immunostains was determined with BioQuant Image Analysis (R\&M Biometrics, Nashville, TN) and averaged in two areas $\left(0.04 \mathrm{~mm}^{2}\right.$ each $)$ of the molecular layer of the dentate gyrus and of the stratum radiatum of the CA1 region. Relative calbindin-IR levels were expressed as the ratio of IODs in the molecular layer and in the stratum radiatum of the same section. The mean ratio of nontransgenic (NTG) mice was defined as 1 . The relative numbers of Fos-IR, phospho-ERK1/2-IR, and Arc-IR granule cells were determined by counting labeled cells in the granular layer in every 10th serial coronal section throughout the rostrocaudal extent of the granular layer. For plaque-load determination, the average percentage area of the hippocampus occupied by A $\beta$-IR deposits was determined in four coronal sections (300 $\mu \mathrm{m}$ apart) per mouse, as described previously (Mucke et al., 2000).

Vibratome sections $(50 \mu \mathrm{m})$ were labeled with anti-glial fibrillary acidic protein (GFAP; 1:500; Chemicon, Temecula, CA) as described previously (Toggas et al., 1994; Mucke et al., 1995), followed by a biotinylated species-specific secondary IgG (1:200; Vector Laboratories). After development with diaminobenzidine, relative levels of immunoreactivity were determined densitometrically with a Quantimet 570C (Leica, Arcadia, CA).

Immunoprecipitation and Western blot analysis. A McIlwain tissue chopper was used to cut hemibrains into $450-\mu \mathrm{m}$-thick horizontal sections from which the dentate gyrus was microdissected on ice. For protein quantitations, dentate gyrus samples from each hemibrain were pooled and homogenized on ice in buffer containing $320 \mathrm{~mm}$ sucrose, 10 mм Tris-HCl, pH 7.4, 10 mм EDTA, 10 mм EGTA, 1\% deoxycholate, 1 mM PMSF, Phosphatase Inhibitor Cocktails I and II (Sigma), and protease inhibitor mixture (Roche). Samples were then briefly sonicated on ice and centrifuged at $5000 \times g$ for $10 \mathrm{~min}$. Equal amounts of protein (determined by the Bradford assay) were resolved by SDS-PAGE on $4-12 \%$ gradient gels and transferred to nitrocellulose membranes. For immunoprecipitations, $70 \mu \mathrm{g}$ of protein were incubated overnight at $4^{\circ} \mathrm{C}$ with $5 \mu$ l of goat-anti-Fyn polyclonal antibody (Santa Cruz Biotechnology, Santa Cruz, CA). Protein G-coupled magnetic beads were then added to precipitate antibody-bound proteins. After washing the beads, $2 \times$ sample buffer was added to liberate the antibody-protein complexes, and samples were resolved by SDS-PAGE. For analysis of phosphoproteins, membranes were labeled with anti-Tyr ${ }^{416}$, which recognizes active Fyn (1:1000; rabbit polyclonal; Cell Signaling), followed by incubation with HRP-conjugated goat anti-rabbit IgG (1:5000; Chemicon) secondary antibody. For analysis of total Fyn levels, blots were stripped 

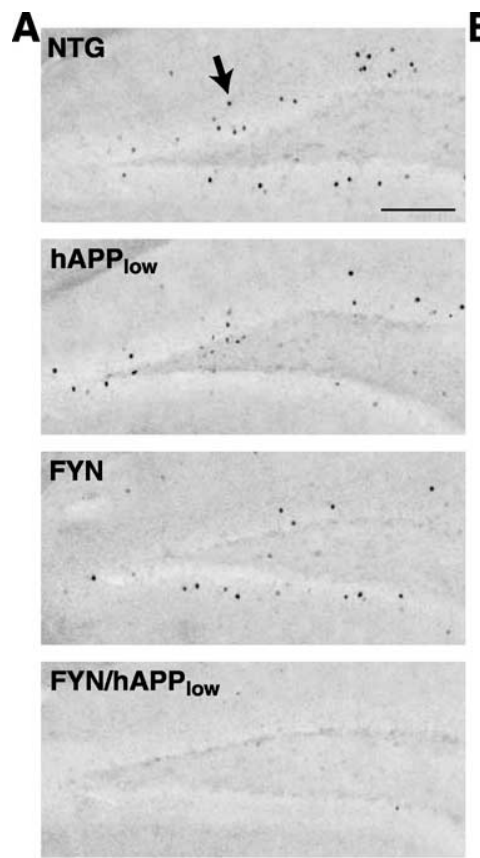

C

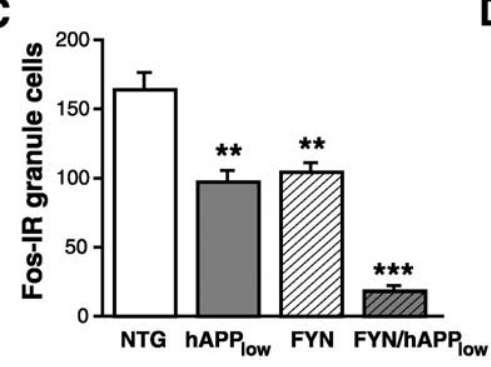

Figure 2. $\mathrm{hAPP} / \mathrm{A} \beta$ and Fyn cooperate to diminish the number of Fos-positive granule cells in FYN/hAPP mice. $A$, Immunostaining for Fos demonstrates a typical pattern of granule cell labeling (arrow) in the dentate gyrus of an NTG mouse and different degrees of Fos reduction in TG mice. FYN/hAPP mice were affected most severely. $\boldsymbol{B}$, Calbindin levels correlated with the number of Fos-positive granule cells in singly and doubly TG mice but not in NTG controls. The $p$ and $R^{2}$ values refer to TG groups only. $\boldsymbol{C}, \boldsymbol{D}$, Quantitation of Fos-positive granule cells revealed significant reductions in $\mathrm{hAPP}$ low and FYN mice (C). FYN/hAPP low mice had more severe depletions (C) that were of similar magnitude as those in hAPP ${ }_{\text {high }}$ mice $(\boldsymbol{D}) . n=23-37$ (C) or $n=9$ (D) mice per genotype. ${ }^{* *} p<0.01,{ }^{* * *} p<0.001$ versus NTG. Scale bar, $100 \mu \mathrm{m}$.

and reprobed with anti-Fyn (1:1000; mouse monoclonal; BD Transduction Laboratories, San Jose, CA). The following antibodies were used for Western blot analyses and detected with species-appropriate HRPconjugated secondary antibodies: anti-human APP (1:1000; Elan Pharmaceuticals), anti-striatal-enriched phosphatase (STEP; 1:5000; mouse monoclonal; Novus Biologicals, Littleton, CO), anti- $\alpha 7$ nAChR (1:1000; mouse monoclonal; Covance, Princeton, NJ), and anti-calbindin (1:15,000; rabbit polyclonal; Swant). Bands were visualized by ECL and quantitated densitometrically with Quantity One 4.0 software (Bio-Rad, Hercules, CA).

Novel environment. Mice were singly housed for $3 \mathrm{~d}$ before the experiment. Mice assigned to novel environment exploration were transferred to an adjacent room that was different in size, shape, light, and furnishing and placed into another cage. The new cage was kept uncovered and contained a different type of bedding as well as five novel objects. The mice were allowed to explore the new environment for $2 \mathrm{~h}$, whereas the remaining mice were kept undisturbed in their home cages.

The activity of the mice and their interactions with the novel objects were quantified from video records during the first $10 \mathrm{~min}$ of each hour the mice spent in the new cage. Activities included ambulatory movements, rearing, sniffing, and digging. Overall activity was counted as the
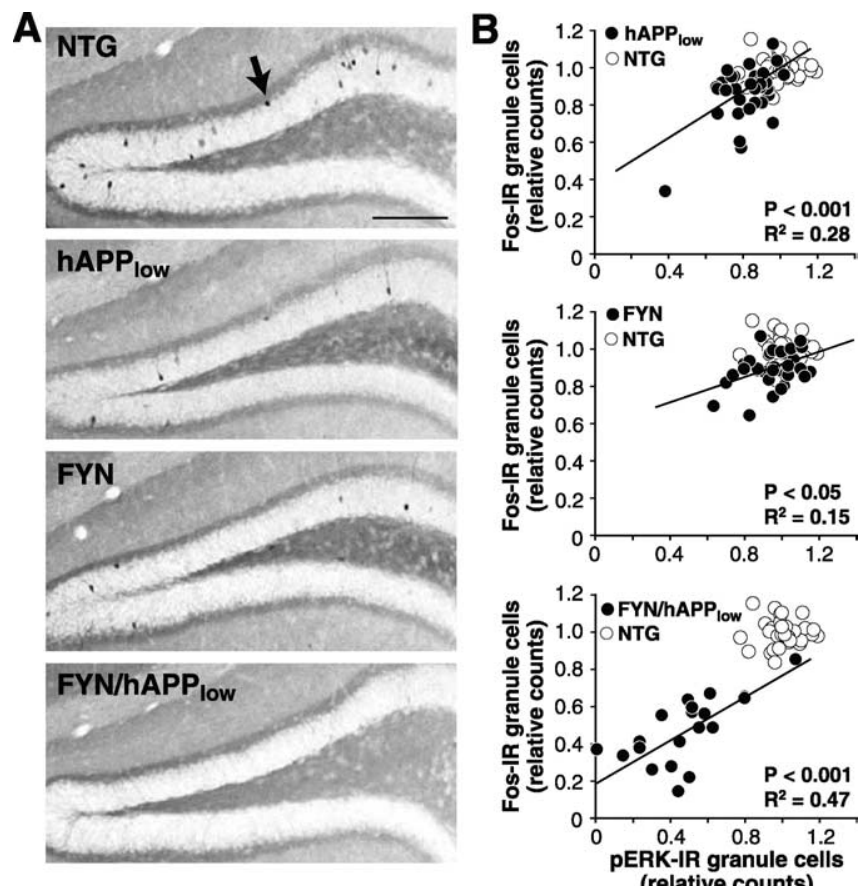

C

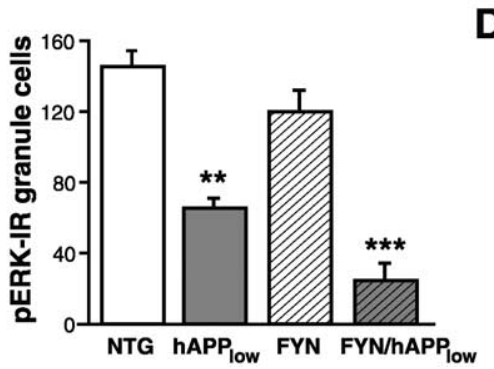

D

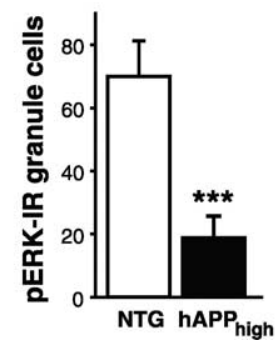

Figure 3. hAPP/A $\beta$ and Fyn cooperate to diminish the number of pERK1/2-positive granule cells in FYN/hAPP low mice. $A$, Immunostaining for phosphorylated ERK1/2 (pERK1/2) demonstrates a typical pattern of granule cell labeling (arrow) in the dentate gyrus of an NTG mouse and different degrees of pERK1/2 reduction in TG mice. FYN/hAPP ${ }_{\text {low }}$ mice were affected most severely. $\boldsymbol{B}$, Significant correlations between the numbers of pERK1/2-and Fos-positive granule cells were identified in singly and doubly TG mice but not in NTG controls. The $p$ and $R^{2}$ values refer to TG groups only. $C, D$, Quantitation of pERK1/2-positive granule cells revealed a significant reduction in $\mathrm{hAPP}_{\text {low }}$ mice $(\boldsymbol{C})$. FYN/hAPP low mice had more severe depletions $(\boldsymbol{C})$ that were of similar magnitude as those in hAPP high $_{\text {mice }}(\boldsymbol{D}) . n=23-37(\boldsymbol{C})$ or $n=9$ (D) mice per genotype. ${ }^{* *} p<0.01,{ }^{* * *} p<0.001$ versus NTG. Scale bar, $100 \mu \mathrm{m}$.

proportion of time the mice were engaged in any of these behaviors. An object interaction event was defined as any type of close exploratory activity with any of the five novel objects. Observers were blinded with respect to the genotype of mice.

At the end of the observation period, alternate mice assigned to the home cage or novel environment condition were taken to another room, deeply anesthetized, and perfused transcardially.

Morris water maze. The water maze pool (diameter, $122 \mathrm{~cm}$ ) contained opaque water $\left(22-23^{\circ} \mathrm{C}\right)$ with a platform (diameter, $\left.10 \mathrm{~cm}\right)$ submerged $1.5 \mathrm{~cm}$. A black and white striped mast ( $15 \mathrm{~cm}$ in height) was mounted on the platform for cued training sessions and removed for hidden platform sessions. For hidden platform sessions, the platform $(14 \times 14 \mathrm{~cm})$ was submerged $1.5 \mathrm{~cm}$ and was not cued. Mice were trained to locate the cued platform (sessions 1-6) and the hidden platform (sessions 7-16) in two daily sessions ( $3.5 \mathrm{~h}$ apart), each consisting of two $60 \mathrm{~s} \mathrm{trials} \mathrm{(cued} \mathrm{train-}$ ing) or three $60 \mathrm{~s}$ trials (hidden training) with a $15 \mathrm{~min}$ intertrial interval. The platform location was changed for each cued platform session but remained constant in the hidden platform sessions. Entry points were changed semirandomly between trials. Twenty-four hours after completion of the hidden platform training, a $60 \mathrm{~s}$ probe trial (platform re- 
A

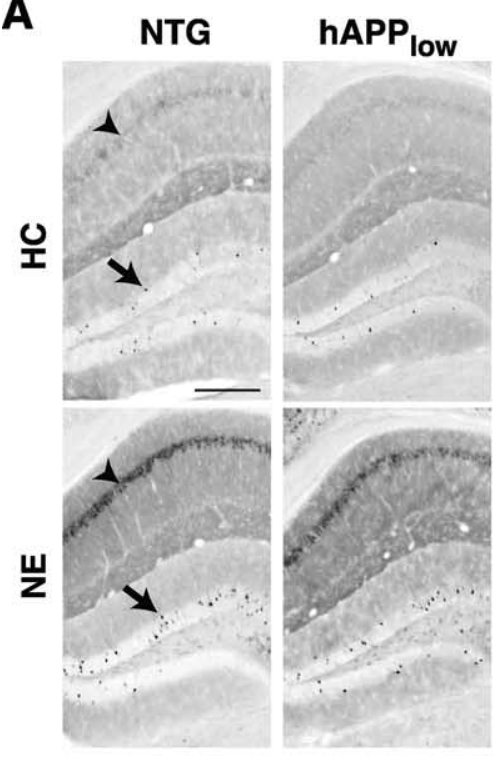

B

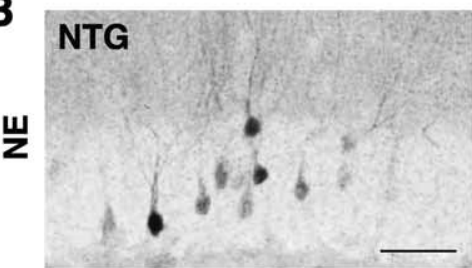

C
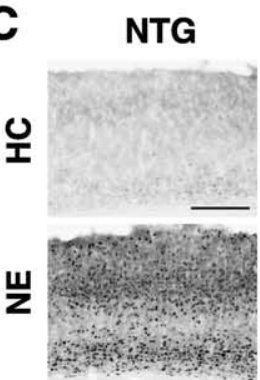

hAPP

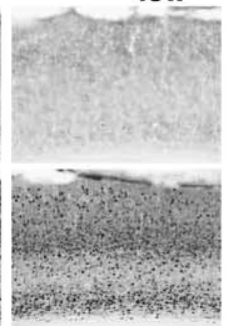

FYN
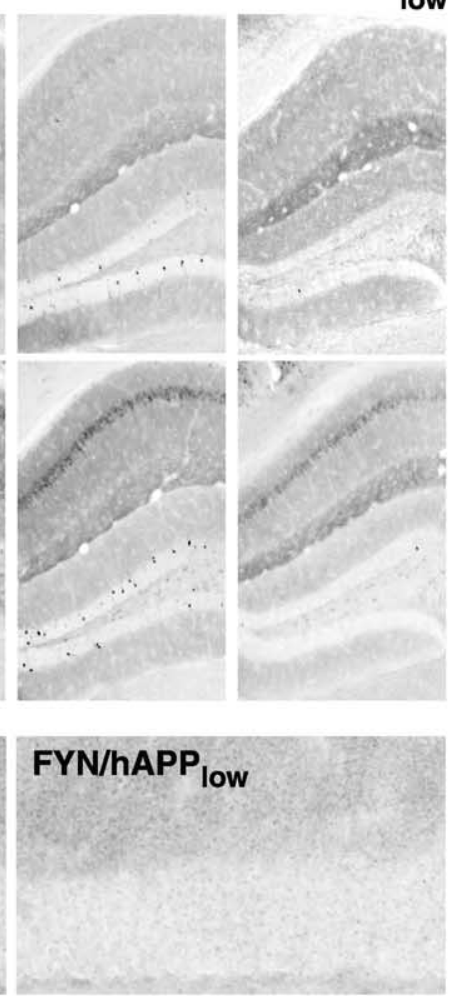

FYN

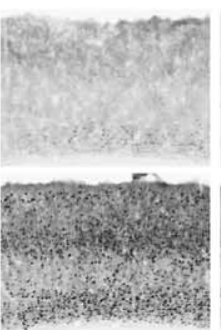

FYN/hAPP
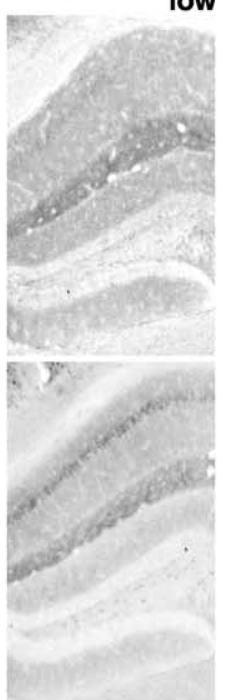

FYN/hAPP ${ }_{\text {low }}$

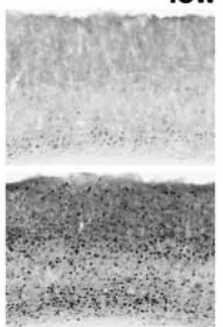

D

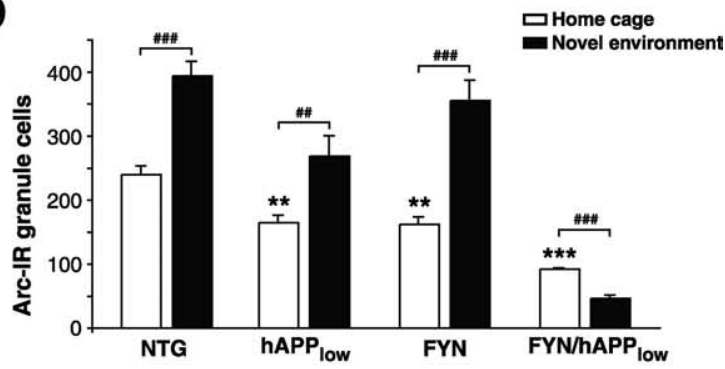

E

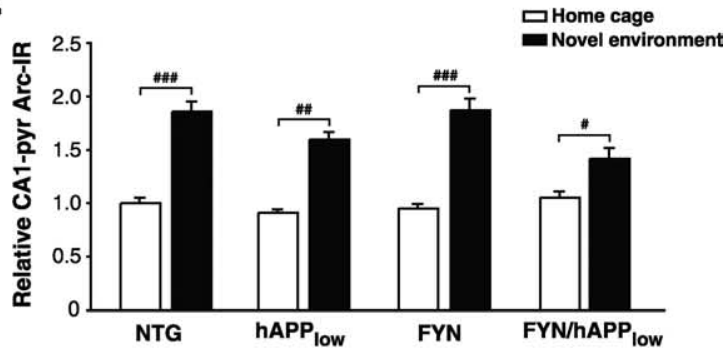

F

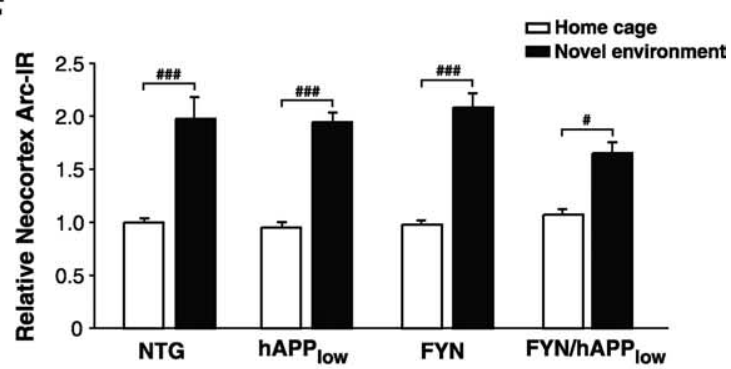

Figure 4. Impaired induction of Arc expression in FYN/hAPP ${ }_{\text {low }}$ mice. $A$, Micrographs demonstrating Arc-IR granule cells in the dentate gyrus (arrow) and pyramidal cells in CA1 (arrowhead) in home-caged mice (HC; top) and mice that had explored a novel environment (NE; bottom). $\boldsymbol{B}$, High-magnification micrographs illustrating that granule cells in the dentate gyrus were Arc immunoreactive in an NTG mouse (left), but not in a FYN/hAPP low mouse (right), after exploration of a novel environment. C, Micrographs demonstrating Arc-IR cells in the neocortex of mice that had (bottom) or had not (top) explored the novel environment. $\boldsymbol{D}-\boldsymbol{F}$, Quantitation of Arc immunolabeling ( $n=3-10$ mice per genotype and condition) demonstrates that environmental exploration increased the number of Arc-positive granule cells in NTG and singly TG mice but not in FYN/hAPP low mice (D). In contrast, environmental exploration increased Arc induction in the pyramidal (Pyr) cell layer of the CA1 region $(\boldsymbol{E})$ and the neocortex $(\boldsymbol{F})$ also in FYN/hAPP low mice, although to a somewhat lesser extent than in NTG and FYN mice. For CA1 and neocortex data, measurements in each bar were normalized against the mean of the home-caged NTG mice. ${ }^{* *} p<0.01$, ${ }^{* * *} p<0.001$ versus NTG by ANOVA; ${ }^{\# \#} p<0.01,{ }^{\# \# \#} p<0.001$ by Fisher's PLSD post hoc test. Scale bars: $\boldsymbol{A}, \boldsymbol{C}, 250 \mu \mathrm{m} ; \boldsymbol{B}, 50 \mu \mathrm{m}$.

moved) was performed. Entry points for probe trials were in the west quadrant, and the target quadrant was the southeast quadrant. Performance was monitored with an EthoVision video-tracking system (Noldus Information Technology, Wageningen, The Netherlands).

Elevated plus maze. The elevated plus-shaped maze consisted of two open arms and two closed arms equipped with rows of infrared photocells interfaced with a computer (Hamilton, Poway, CA) as described previously (Raber et al., 2000). Briefly, mice were placed individually into the center of the maze and allowed to explore the apparatus for $10 \mathrm{~min}$. The number of beam breaks was recorded to calculate the amount of time spent and distance moved in each arm, as well as the number of times the mice extended over the edges of the open arms. The apparatus was cleaned with $0.25 \%$ bleach between the testing of each mouse to standardize odors.

Statistical analyses. Statistical analyses were performed with Statview 5.0 (SAS Institute, Cary, NC) or SPSS-10 (SPSS, Chicago, IL). Differences between means were assessed by Student's $t$ test, Mann-Whitney $U$ test, one-factor ANOVA, or two-factor ANOVA, followed by Tukey-Kramer or Fisher's PLSD post hoc tests. Correlations were assessed by simple regression analysis. The numbers of IR cells analyzed in the regressions are shown as relative values (compared with the mean of NTG mice) of the natural log of the total numbers of IR cells counted in each mouse.

\section{Results}

To test for copathogenic effects between hAPP/A $\beta$ and Fyn, we crossed heterozygous TG mice from a PDGF-hAPP line with moderate levels of neuronal hAPP/A $\beta$ expression (J9, "hAPP ${ }_{\text {low }}$ ") (Hsia et al., 1999; Mucke et al., 2000; Chin et al., 2004) with heterozygous TG mice from a CamKII $\alpha$-FYN line (line N8) with increased neuronal levels of wild-type mouse Fyn (Kojima et al., 1997, 1998). The cross yielded four genotypes: NTG mice, singly TG hAPP mice, singly TG FYN mice, and doubly TG FYN/hAPP mice. These groups of mice were com- 
pared with heterozygous TG mice from a PDGF-hAPP line with higher levels of neuronal hAPP/A $\beta$ expression (J20, "hAPP ${ }_{\text {high }}$ ") (Mucke et al., 2000; Palop et al., 2003; Chin et al., 2004).

Increased expression of Fyn exacerbates hAPP/A $\beta$-induced depletion of calbindin and Fos

The calcium-binding protein calbindin- $\mathrm{D}_{28 \mathrm{k}}$ regulates intracellular calcium levels and is important for long-term potentiation and for learning and memory (Molinari et al., 1996). It is markedly reduced in the dentate gyrus of many, but not all, $\mathrm{hAPP}_{\text {high }}$ mice in a manner that strongly correlates with impaired performance in the Morris water maze (Palop et al., 2003). Calbindin levels in granule cells of the dentate gyrus were only slightly reduced in singly TG hAPP ${ }_{\text {low }}$ mice and unaffected in singly TG FYN mice compared with NTG controls (Fig. 1). In contrast, doubly TG FYN/hAPP low mice had profound depletions of calbindin (Fig. $1 A, B$ ) that were similar in magnitude to those in age-matched singly TG hAPP high mice without the FYN transgene (Fig. 1C). These results were confirmed by Western blot analysis of dentate gyrus lysates, which demonstrated lower calbindin levels in FYN/hAPP ${ }_{\text {low }}$ mice than in NTG mice and singly TG controls (Fig. $1 D$, bottom). hAPP (Fig. $1 D$, top) and Fyn levels (Fig. $1 D$, middle) are shown to illustrate the similar extent to which these proteins are overexpressed in $\mathrm{FYN} / \mathrm{hAPP}$ low mice and in the corresponding singly TG controls.

Calbindin depletions in the dentate gyrus of $\mathrm{hAPP}_{\text {high }}$ mice correlate tightly with reductions in Fos-positive granule cells (Palop et al., 2003). hAPP ${ }_{\text {low }}$ and FYN singly TG mice had fewer Fos-positive granule cells than NTG controls (Fig. $2 A, C$ ), although only FYN/hAPP ${ }_{\text {low }}$ mice had Fos reductions as severe as those in hAPP high mice (Fig. 2D). Decreases in Fos-positive granule cells correlated with calbindin reductions in mice of all TG genotypes in which Fos levels were reduced (Fig. $2 B$ ), suggesting that Fos and calbindin were affected by a common mechanism.

\section{Fyn and hAPP/A $\beta$ decrease the activity of ERK $1 / 2$ in the dentate gyrus}

The expression of Fos and other immediate-early genes is controlled by transcription factors, the nuclear translocation and transcriptional activity of which are regulated by synaptic activity-dependent kinases such as ERK1/2 (Kelleher et al., 2004; Sweatt, 2004). To test whether the reduction in Fos might be related to impaired ERK1/2 activity, we examined the expression of dually phosphorylated (activated) ERK1/2 in granule cells. Similar to the results obtained for Fos, the number of phosphoERK1/2-positive granule cells was significantly reduced in singly TG hAPP ${ }_{\text {low }}$ mice and most severely affected in $\mathrm{FYN} / \mathrm{hAPP}$ low mice (Fig. $3 A-C$ ). Once again, the reductions in phosphoERK1/2-positive granule cells in FYN/hAPP ${ }_{\text {low }}$ mice matched those in hAPP ${ }_{\text {high }}$ mice (Fig. 3D). The numbers of Fos-positive and phospho-ERK-positive granule cells were correlated in all groups of TG mice, suggesting that these proteins are coregulated (Fig. 3B).

Combined expression of Fyn and hAPP/A $\beta$ impairs induction of Arc expression after exploration of a novel environment ERK1/2 also regulates the expression of the immediate-early gene product Arc (Waltereit et al., 2001; Kremerskothen et al., 2002; Ying et al., 2002). Arc is highly enriched in dendrites of hippocampal neurons where it binds to cytoskeletal elements (Lyford et al., 1995) and has been characterized for the accumulation of its mRNA and protein in segments of dendrites that were recently active (Steward et al., 1998). Exploration of a novel envi-
A

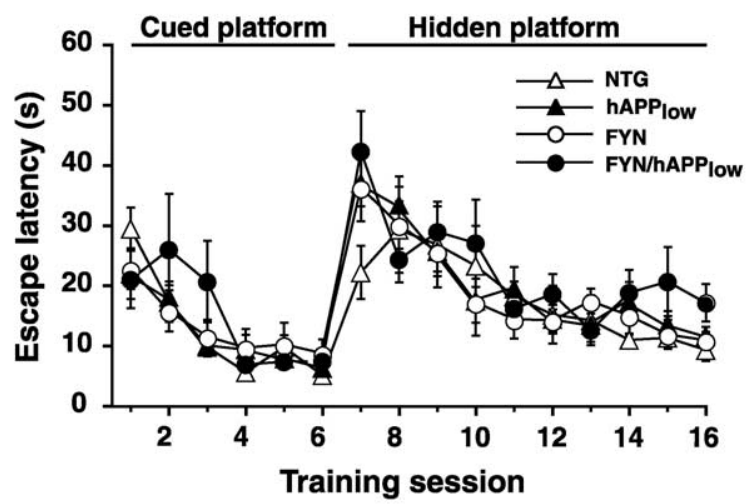

B
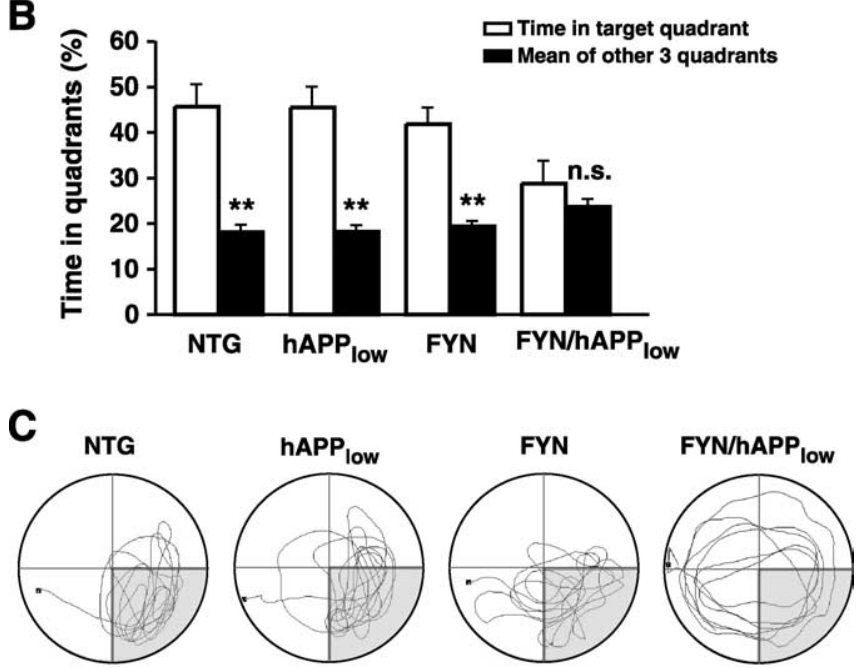

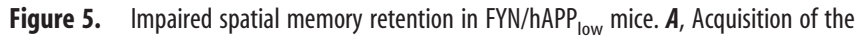
cued and hidden platform portions of the Morris water maze test was similar in all groups of mice ( $n=7-11$ per genotype). $\boldsymbol{B}$, During the probe trial (platform removed), FYN/hAPP low mice showed no preference for the target quadrant, whereas NTG, hAPP low' $^{\prime}$ and FYN mice spent significantly more time searching the target quadrant than the other three quadrants. ${ }^{* *} p<$ 0.01 versus target quadrant by Student's $t$ test. $\boldsymbol{C}$, Representative examples of swim paths during the probe trial. Shading indicates the target quadrant.

ronment has been shown to induce Arc expression in dentate granule cells (Guzowski et al., 1999; Pinaud et al., 2001; Chawla et al., 2005). Novel environment exploration strongly increases Arc expression in granule cells of the dentate gyrus in NTG mice but not in $\mathrm{hAPP}_{\text {high }}$ mice (Palop et al., 2005). In contrast, singly TG $\mathrm{hAPP}_{\text {low }}$ and FYN mice showed normal Arc induction in this paradigm, although their basal Arc levels were lower than those of NTG littermates (Fig. 4A,D). Notably, FYN/hAPP ${ }_{\text {low }}$ mice had more prominent reductions in basal Arc levels and actually showed a decrease in Arc expression instead of an increase after environmental exploration (Fig. $4 A, B, D$ ). No significant differences were found in locomotion or object interactions among the four genotypes (data not shown). All groups of mice showed similar basal levels of Arc and comparable Arc induction in the pyramidal cell layer of CA1 (Fig. 4A,E) and in the neocortex (Fig. $4 C, F)$, although the induction was slightly attenuated in $\mathrm{hAPP}_{\text {low }}$ and $\mathrm{FYN} / \mathrm{hAPP}_{\text {low }}$ mice. The selective deficit in basal and induced Arc expression in the dentate gyrus of doubly TG FYN/hAPP ${ }_{\text {low }}$ mice is very similar to that observed in singly $\mathrm{TG} h A P P_{\text {high }}$ mice (Palop et al., 2005), suggesting that Fyn and hAPP/A $\beta$ act synergistically to impair Arc expression in a brain region-specific manner. 


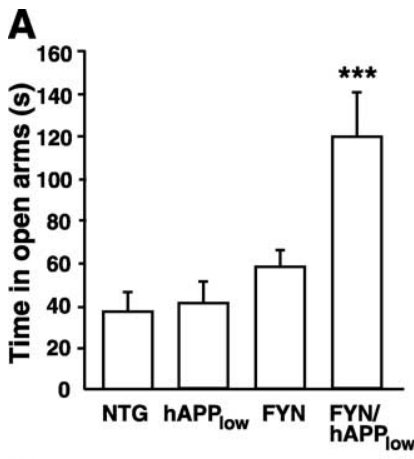

C
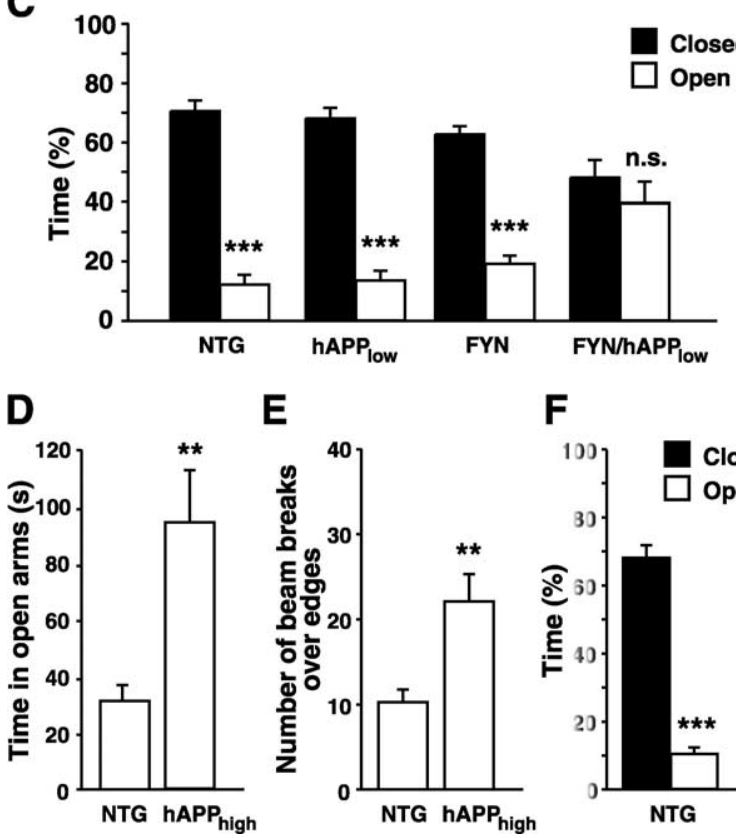

$\mathrm{E}$

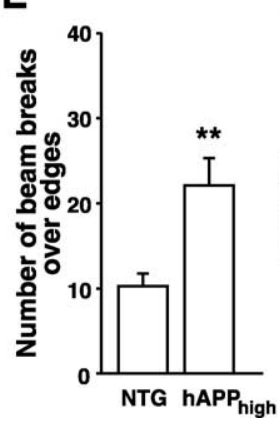

$\mathbf{F}$

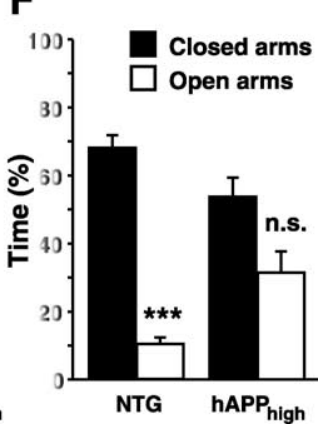

Figure 6. Behavioral alterations of FYN/hAPP low mice in the elevated plus maze. $\boldsymbol{A}, \boldsymbol{B}$, FYN/

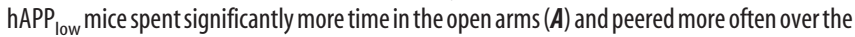
edges of the maze $(\boldsymbol{B})$ than the other three groups ( $n=15-25$ mice per genotype). $\boldsymbol{C}$, FYN/

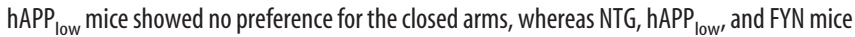
spent significantly more time in the closed arms than in the open arms of the maze. $\boldsymbol{D}-\boldsymbol{F}$, Compared with NTG controls, singly TG hAPP high mice also spent more time in the open arms $(\boldsymbol{D})$, peered over the edges of the apparatus more often $(\boldsymbol{E})$, and showed no significant preference for the closed arms $(\boldsymbol{F})\left(n=12-13\right.$ mice per genotype). ${ }^{*} p<0.01$ versus NTG by Student's $t$ test $(\boldsymbol{D}, \boldsymbol{E}) ;{ }^{* * *} p<0.001$ versus NTG by ANOVA $(\boldsymbol{A}, \boldsymbol{B})$ or versus closed arms by Student's $t$ test $(\boldsymbol{C}, \boldsymbol{F})$.

Cooperation of Fyn and hAPP/A $\beta$ impairs spatial memory retention and alters emotional behavior

Because the molecules that were reduced in the dentate gyrus of $\mathrm{FYN} / \mathrm{hAPP}_{\text {low }}$ mice are critically involved in the formation or consolidation of memories (Molinari et al., 1996; Atkins et al., 1998; Blum et al., 1999; Guzowski et al., 2000; Guzowski, 2002; He et al., 2002), we next assessed the spatial learning and memory of mice in the Morris water maze. NTG, hAPP low,$F Y N$, and $\mathrm{FYN} / \mathrm{hAPP}_{\text {low }}$ mice were able to learn both the cued (platform location visible) and the spatial (platform hidden) components of this task (Fig. 5A). However, when retention of spatial memory was tested in a probe trial $24 \mathrm{~h}$ after the last training trial, only $\mathrm{FYN} / \mathrm{hAPP}_{\text {low }}$ mice were impaired, showing no preference for the target quadrant based on comparisons of the time they spent in each quadrant (Fig. 5B) and of their swim paths (Fig. 5C). $\mathrm{hAPP}_{\text {high }}$ mice have similar probe trial deficits, although many of these mice also show deficits in task acquisition (Palop et al., 2003).
A
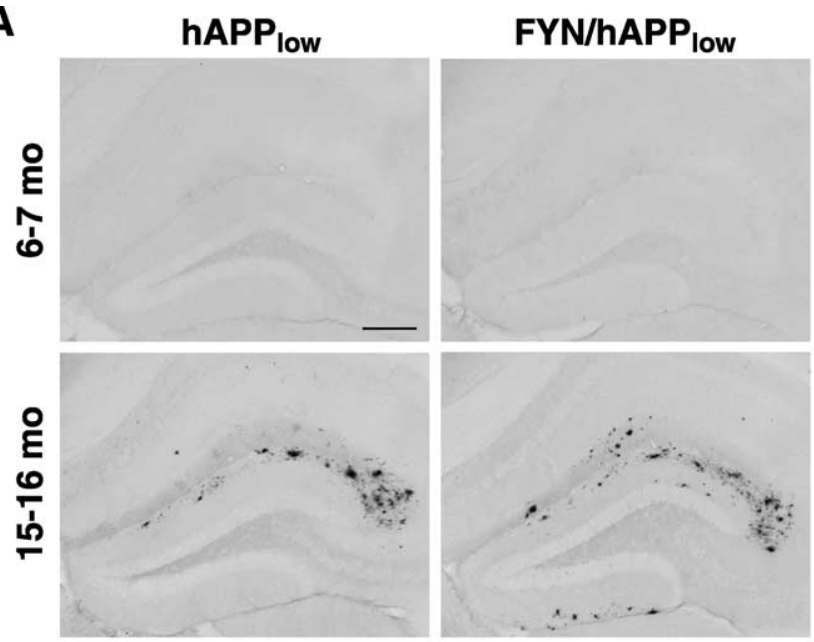

B

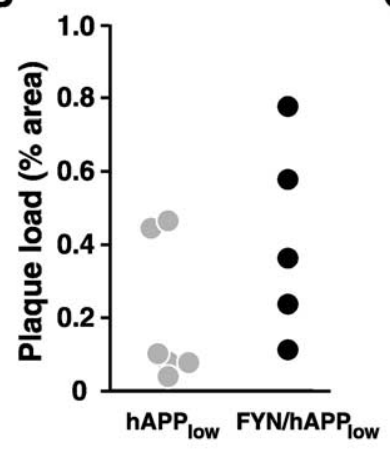

C

D
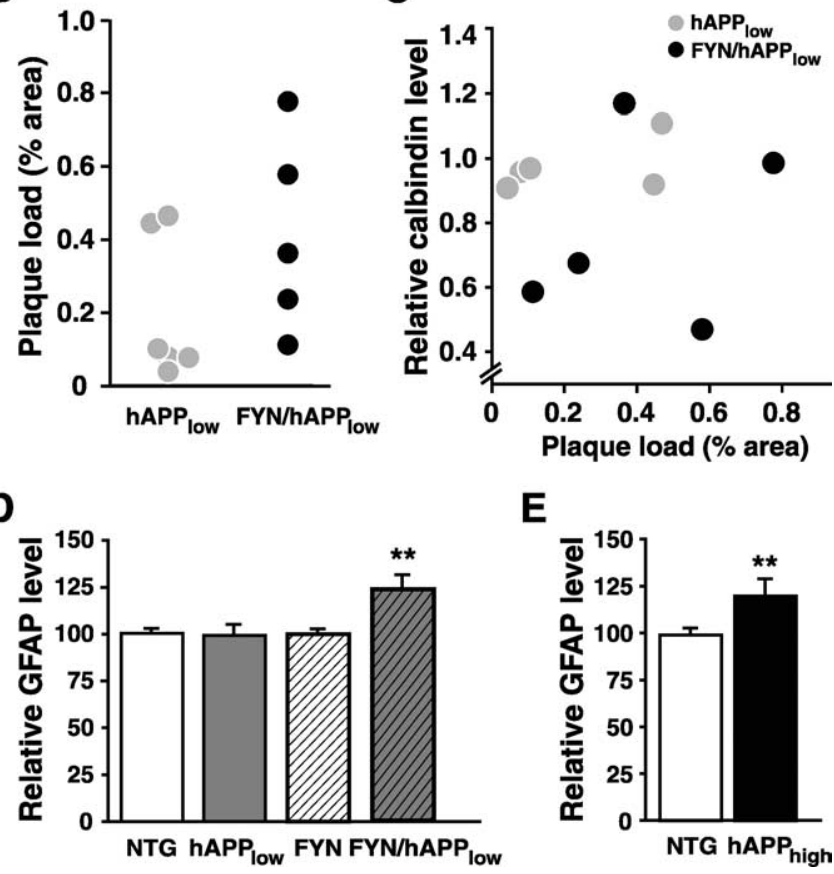

E

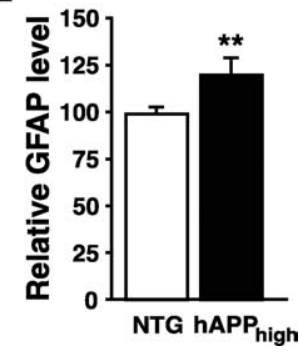

Figure 7. Overexpression of Fyn does not affect amyloid deposition but elicits an astroglial injury response in FYN/hAPP low mice. $A$, At $6-7$ months ( $\mathrm{mo}$ ) of age (top), immunostaining for $A \beta$ revealed no amyloid deposits in $\mathrm{hAPP}_{\text {low }}$ and FYN/hAPP low mice. At $15-16$ months (bottom), these mice had comparable levels of amyloid deposition. $\boldsymbol{B}$, Quantitation of amyloid deposition in 15- to 16-month-old mice. C, Plaque load did not correlate with calbindin levels in

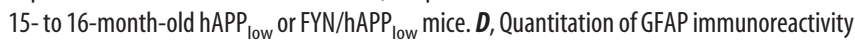
in 6- to 7-month-old mice revealed increased astroglial GFAP expression indicative of reactive astrocytosis in $\mathrm{FYN} / \mathrm{hAPP}$ low mice relative to NTG or singly TG mice $(n=8-12$ per genotype). $\boldsymbol{E}$, Age-matched hAPP ${ }_{\text {high }}$ mice had similar increases in GFAP expression ( $n=10$ per genotype). ${ }^{* *} p<0.01$ versus NTG by ANOVA (D) or Student's $t$ test $(\boldsymbol{E})$. Scale bar, $250 \mu \mathrm{m}$.

To determine whether Fyn and hAPP/A $\beta$ may interact also in brain regions other than the dentate gyrus, we examined the behavior of the mice in the elevated plus maze, a paradigm that provides putative measures of emotionality and exploratory behaviors that are mostly independent of the hippocampus (Dawson and Tricklebank, 1995; Wall and Messier, 2001). The

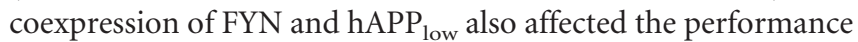
of mice in the elevated plus maze. $\mathrm{FYN} / \mathrm{hAPP}_{\text {low }}$ mice spent significantly more time in the open arms of the maze and poked their noses over the edges of the open arms more often than $\mathrm{hAPP}_{\text {low }}$ mice, FYN mice, and NTG controls (Fig. 6A,B). FYN/ 
$\mathrm{hAPP}_{\text {low }}$ mice showed no significant preference for the closed arms over the open arms of the maze, in contrast to the other three groups of mice (Fig. $6 \mathrm{C}$ ). These behavioral alterations of $\mathrm{FYN} / \mathrm{hAPP} \mathrm{P}_{\text {low }}$ mice are remarkably similar to those of $\mathrm{hAPP}_{\text {high }}$ mice in this test (Fig. 6D-F).

Increased Fyn expression does not affect amyloid deposition

We previously used ELISA to demonstrate that neither increasing nor ablating Fyn expression affects hippocampal $A \beta$ levels in 6- to 7-month-old mice (Chin et al., 2004). To determine whether the exacerbation of hAPP/A $\beta$-induced neuronal and behavioral alterations by Fyn could stem from changes in the deposition of $\mathrm{A} \beta$, we compared $\mathrm{A} \beta$ deposits (plaque load) in $\mathrm{hAPP}_{\text {low }}$ and FYN/hAPP ${ }_{\text {low }}$ mice. At 6-8 months, the age at which all other biochemical, immunohistochemical, and behavioral experiments were performed, no plaques were detected in the hippocampus of these mice (Fig. 7A, top). By 15-16 months of age, $\mathrm{hAPP}_{\text {low }}$ and $\mathrm{FYN} / \mathrm{hAPP}$ low

mice had comparable hippocampal plaque loads (Fig. 7A,B) ( $p=0.13$; Mann-Whitney $U$ test). No correlation was found between plaque load and calbindin levels in either $\mathrm{hAPP}_{\text {low }}$ or FYN/hAPP ${ }_{\text {low }}$ mice (Fig. 7C) at this age.

Increased astroglial injury response in $\mathrm{FYN} / \mathrm{hAPP}{ }_{\text {low }}$ mice Astrocytes upmodulate the expression of GFAP in response to a variety of neural injuries (Eddleston and Mucke, 1993; Eng et al., $2000)$. We analyzed this sensitive indicator of neuronal distress at 6-8 months of age. Hippocampal GFAP levels in hAPP ${ }_{\text {low }}$ and FYN mice were similar to those of NTG controls, whereas FYN/ $\mathrm{hAPP}_{\text {low }}$ mice had significantly higher levels of GFAP labeling (Fig. 7D). This increase in GFAP expression in FYN/hAPP mice without plaques was similar in magnitude to that in agematched hAPP ${ }_{\text {high }}$ mice with plaques (Fig. 7E).

Regulation of Fyn activity in hAPP ${ }_{\text {high }}$ and FYN/hAPP ${ }_{\text {low }}$ mice To determine whether hAPP/A $\beta$ actually increases Fyn activity in vivo, we immunoprecipitated Fyn from dentate gyrus lysates of

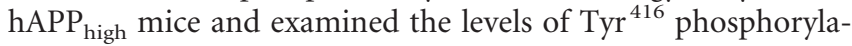
tion with a phospho-specific antibody. Phosphorylation at this site activates Fyn and is indicative of kinase activity (Nguyen et al., 2002; Roskoski, 2004; Santuccione et al., 2005). In hAPP ${ }_{\text {high }}$ mice with relatively preserved levels of calbindin (higher than the average of all hAPP ${ }_{\text {high }}$ mice), levels of active Fyn were similar to those in NTG mice. In contrast, $\mathrm{hAPP}_{\text {high }}$ mice with prominent depletions of calbindin (levels lower than the average of all hAP$\mathrm{P}_{\text {high }}$ mice) exhibited decreased levels of active Fyn (Fig. 8A). Notably, our previous studies demonstrated that the extent of calbindin depletion in $\mathrm{hAPP}$ high mice correlates tightly with the severity of learning and memory deficits in the Morris water maze test (Palop et al., 2003).

Next, we examined whether levels of active Fyn were also different in FYN and FYN/hAPP low $_{\text {mice. Although levels of total }}$ Fyn were similar in these groups (Figs. $1 D, 8 B$, bottom blot), levels of active Fyn were strikingly lower in FYN/hAPP ${ }_{\text {low }}$ mice than in FYN mice (Fig. $8 B$ ).
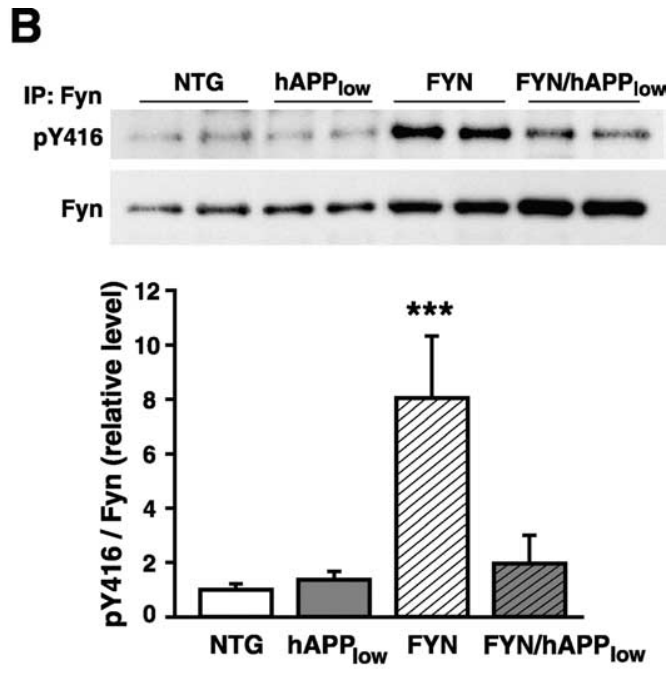

Concurrent increases in STEP and $\alpha 7 \mathrm{nAChR}$ in $\mathrm{hAPP}_{\text {high }}$ and FYN/hAPP low $_{\text {mice }}$

What regulatory mechanisms might underlie the surprising downmodulation of Fyn in hAPP ${ }_{\text {high }}$ and FYN/hAPP low $_{\text {mice? To }}$ begin to address this question, we measured the $61 \mathrm{kDa}$ form of STEP, which associates with and dephosphorylates Fyn at the regulatory $\mathrm{Tyr}^{416}$ (Nguyen et al., 2002). STEP is present at postsynaptic densities of glutamatergic synapses and interacts with both src kinase family members and NMDA receptors, opposing src-mediated upregulation of NMDA receptors (Pelkey et al., 2002). STEP levels were indeed significantly increased in the dentate gyrus of $\mathrm{hAPP}_{\text {high }}$ mice relative to NTG controls (Fig. $9 A$ ). Because $A \beta$ has recently been shown to activate STEP in cultured neurons via $\alpha 7$ nAChRs (Snyder et al., 2005), we measured $\alpha 7 \mathrm{nAChR}$ levels in the dentate gyrus of our mice. The $\alpha 7$ $\mathrm{nAChR}$ levels were approximately twice as high in $\mathrm{hAPP}_{\text {high }}$ mice as in NTG controls (Fig. 9B), indicating that $A \beta$ engages this pathway also in vivo.

Finally, we examined whether STEP and $\alpha 7 \mathrm{nAChRs}$ were also increased in the dentate gyrus of FYN/hAPP ${ }_{\text {low }}$ mice. Compared with NTG and FYN mice, FYN/hAPP ${ }_{\text {low }}$ mice had approximately twofold higher levels of STEP and fivefold higher levels of $\alpha 7$ nAChRs (Fig. 9C-E). STEP levels were also increased in singly TG $\mathrm{hAPP}_{\text {low }}$ mice, although to lesser extent than in FYN/hAPP mice (Fig. 9C,D).

\section{Discussion}

The current study demonstrates that increased neuronal expression of Fyn can promote hAPP/A $\beta$-dependent neuronal and behavioral deficits that may be relevant to the cognitive decline in AD. Elevating neuronal expression of Fyn in hAPP ${ }_{\text {low }}$ mice with relatively minor neuronal deficits created a striking phenocopy of the more severe deficits seen in $\mathrm{hAPP}_{\text {high }}$ mice.

In considering the different possibilities in which Fyn and $\mathrm{A} \beta$ might interact, it is not unreasonable to speculate that Fyn actually mediates the detrimental effects of $\mathrm{A} \beta$. However, our measurements of Fyn activity suggest that Fyn could also act as a 
A

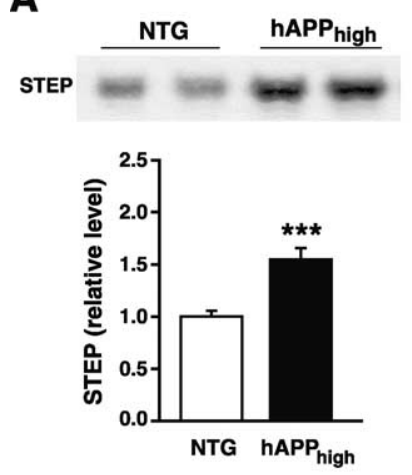

B
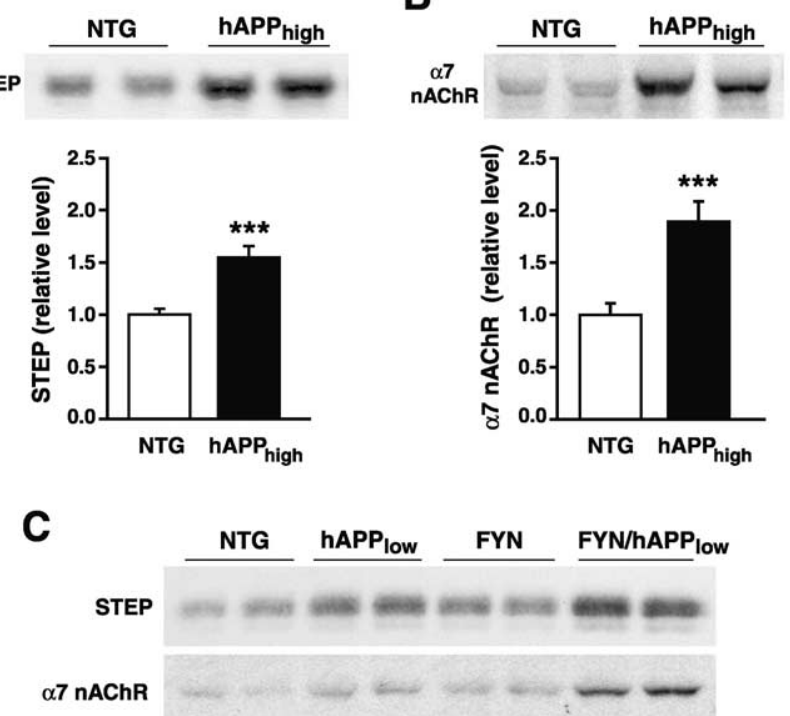

Calbindin

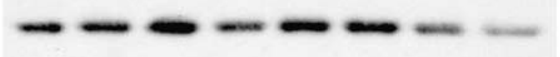

D

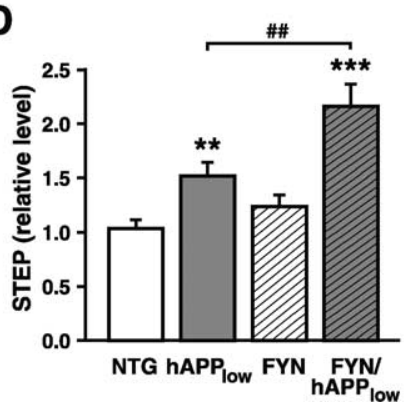

E

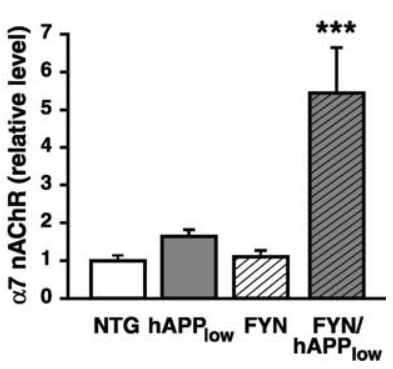

Figure 9. STEP and $\alpha 7 \mathrm{nAChRs}$ are elevated in the dentate gyrus of hAPP ${ }_{\text {high }}$ and FYN/ hAPP ${ }_{\text {low }}$ mice. $A$, Levels of the $61 \mathrm{kDa}$ form of STEP in the dentate gyrus were higher in $\mathrm{hAPP}_{\text {high }}$ mice than in NTG controls ( $n=11-12$ per genotype). $\boldsymbol{B}$, Levels of $\alpha 7$ nAChRs in the dentate gyrus were also significantly elevated in $\mathrm{hAPP}$ high mice ( $n=7$ per genotype). $C$, Representative Western blots illustrating STEP, $\alpha 7 \mathrm{nAChR}$, and calbindin levels in the dentate gyrus of NTG, hAPP low' $_{\text {, }}$ FYN, and FYN/hAPP low mice. $\boldsymbol{D}, \boldsymbol{E}$, Quantitation of STEP (D) and $\alpha 7 \mathrm{nAChR}(\boldsymbol{E})$ levels demonstrates twofold to fivefold increases in these proteins in FYN/hAPP ${ }_{\text {Iow }}$ mice relative to NTG controls ( $n=8-12$ per genotype). ${ }^{* * *} p<0.001$ versus NTG by Student's $t$ test $(\boldsymbol{A}, \boldsymbol{B})$; ${ }^{* *} p<0.01$, ${ }^{* * *} p<0.001$ versus NTG by ANOVA; ${ }^{\# \#} p<0.01$ by PLSD post hoc test (D).

separate copathogenic factor that converges onto similar or identical downstream targets. Compared with NTG controls, $\mathrm{hAPP}_{\text {high }}$ and FYN/hAPP ${ }_{\text {low }}$ mice had more severe neuronal and behavioral deficits than hAPP ${ }_{\text {low }}$ and FYN mice. Yet, Fyn activity was lower in $\mathrm{hAPP}_{\text {high }}$ mice than in NTG controls and was also lower in FYN/hAPP ${ }_{\text {low }}$ mice than in FYN mice. These findings suggest the involvement of complex regulatory mechanisms that may become engaged to protect neurons against synergistic effects of $A \beta$ and Fyn.

In line with this interpretation, we found significant increases in levels of STEP, a phosphatase that inactivates Fyn, in both $\mathrm{hAPP}_{\text {high }}$ and FYN/hAPP ${ }_{\text {low }}$ mice. STEP opposes the phosphorylation of src family kinase substrates such as $\mathrm{Tyr}^{1472}$ of the NR2B subunit of NMDARs (Pelkey et al., 2002). Interestingly, hAPP ${ }_{\text {high }}$ mice have significant decreases in levels of phospho-Tyr ${ }^{1472}$ of NR2B (Palop et al., 2005), consistent with the increased STEP levels and suppressed Fyn activity we detected in these mice in the current study. A $\beta$-induced activation of STEP also led to reduced phospho-Tyr ${ }^{1472}$ of NR2B in cultured neurons, resulting in en- docytosis of the receptor and reduced NMDAR-mediated signaling (Snyder et al., 2005). The study by Snyder et al. (2005) also demonstrated that $\mathrm{A} \beta$ can recruit STEP via $\alpha 7 \mathrm{nAChR}$ dependent signaling. Our identification of abnormally high $\alpha 7$ nAChR levels in both hAPP ${ }_{\text {high }}$ and FYN/hAPP low mice highlights the potential functional relevance of this pathway in vivo. Indeed, increased levels of nAChRs and STEP in hAPP high and $\mathrm{FYN} / \mathrm{hAPP}_{\text {low }}$ mice were associated with depletions of synaptic activity-related proteins that are known to correlate tightly with deficits in learning and memory (Palop et al., 2003, 2005). Unlike the majority of membrane-bound receptors, nAChR expression is increased after receptor stimulation (Fenster et al., 1999), supporting the notion of increased signaling through $\alpha 7 \mathrm{nAChRs}$ in $\mathrm{hAPP}_{\text {high }}$ and $\mathrm{FYN} / \mathrm{hAPP}_{\text {low }}$ mice. $\mathrm{A} \beta$ and Fyn activities may also converge on other cell-surface molecules, including integrins and NMDARs, and these possibilities deserve to be tested in future studies.

Independent of the precise relationship between $\mathrm{A} \beta$ and Fynrelated signaling pathways, the results presented here clearly demonstrate that increased neuronal Fyn expression can critically exacerbate neuronal and behavioral impairments in the context of even relatively moderate increases in $\mathrm{A} \beta$ production. The similarity of impairments in FYN/hAPP ${ }_{\text {low }}$ and $\mathrm{hAPP}$ high mice was essentially complete with respect to molecular alterations and somewhat less complete with respect to behavioral deficits. In the water maze test, $\mathrm{FYN} / \mathrm{hAPP}_{\text {low }}$ mice were impaired only in retention of spatial memory assessed by the $24 \mathrm{~h}$ probe trial, which provides a sensitive measure of hippocampusdependent function (Lipp and Wolfer, 1998; Wolfer et al., 1998). In contrast, $\mathrm{hAPP}_{\text {high }}$ mice were also impaired in task acquisition (Palop et al., 2003). Thus, Fyn signaling may play a more prominent role in hippocampus-dependent memory retention deficits than in acquisition deficits. The possibility of such dissociations is highlighted by our previous study (Chin et al., 2004), which demonstrated that hAPP/A $\beta$-dependent premature mortality and loss of synaptophysin are modulated by Fyn, whereas aberrant axonal sprouting is not.

Although singly TG FYN and hAPP ${ }_{\text {low }}$ mice had no behavioral alterations, both groups showed some depletion of synaptic activity-dependent proteins in granule cells of the dentate gyrus. Although these depletions were less severe than those in $\mathrm{hAPP}_{\text {high }}$ and FYN/hAPP ${ }_{\text {low }}$ mice, they demonstrate that increased neuronal expression of Fyn is sufficient to elicit molecular alterations similar to those induced by moderate levels of hAPP/A $\beta$. These findings also suggest that our molecular outcome measures may be more sensitive than the behavioral tests we used in this study.

Because reductions in Fos, Arc, and ERK1/2 can contribute to deficits in learning and memory (Molinari et al., 1996; Atkins et al., 1998; Blum et al., 1999; Guzowski, 2002; He et al., 2002), it is possible that the neuronal network can compensate for the relatively subtle reduction of these factors in FYN and hAPP ${ }_{\text {low }}$ mice but is overcome by their more severe depletion in $\mathrm{hAPP}_{\text {high }}$ and $\mathrm{FYN} / \mathrm{hAPP}$ low mice, resulting in behavioral decompensation. Consistent with this hypothesis, Arc induction was normal in FYN mice and in $\mathrm{hAPP}_{\text {low }}$ mice, suggesting that activityregulated gene expression was normal. However, there was no induction of Arc in FYN/hAPP ${ }_{\text {low }}$ mice that explored a novel environment. In fact, these mice had even fewer Arc-positive granule cells than home-caged $\mathrm{FYN} / \mathrm{hAPP}_{\text {low }}$ mice, suggesting a paradoxical response of these cells or of the network to which they belong.

FYN/hAPP ${ }_{\text {low }}$ mice also exhibited altered behavior in the elevated plus maze in a manner similar to $\mathrm{hAPP}_{\text {high }}$ mice. This test is 
used to measure emotional behaviors that are mostly independent of the hippocampus (Dawson and Tricklebank, 1995; Wall and Messier, 2001). Thus, the alterations observed in FYN/ $\mathrm{hAPP}_{\text {low }}$ mice in this test suggest that activities of Fyn and $\mathrm{hAPP} / \mathrm{A} \beta$ may interact also in brain regions other than the dentate gyrus. In addition, they suggest that this interaction can contribute not only to memory deficits, but also to alterations in emotional behavior, which afflict both hAPP mice and AD patients (Terry et al., 1991; Cummings and Kaufer, 1996; Lee et al., 2004).

Although increased production of $\mathrm{A} \beta$ may be sufficient to cause early-onset autosomal-dominant AD (Tanzi and Bertram, 2005), the much more frequent cases of late-onset "sporadic" AD are likely caused by the combination of different genetic and environmental risk factors (Mayeux, 2003; Kamboh, 2004; Tanzi and Bertram, 2005). It will be interesting to determine whether some of these risk factors elevate Fyn activity, because our findings suggest that this process could synergize with $A \beta$ to induce neuronal dysfunction. Indeed, increases in neuronal Fyn expression triggered hAPP/A $\beta$-dependent behavioral deficits and worsened the depletion of multiple factors involved in synaptic plasticity.

It is noteworthy in this context that 6- to 8-month-old FYN/ $\mathrm{hAPP}_{\text {low }}$ mice had not yet formed amyloid plaques but in most molecular and behavioral measures were as severely impaired as plaque-bearing $\mathrm{hAPP}_{\text {high }}$ mice of the same age. This finding extends to the molecular level the hypothesis that $\mathrm{A} \beta$-induced behavioral deficits in hAPP mice are primarily plaque independent (Holcomb et al., 1999; Hsia et al., 1999; Westerman et al., 2002; Palop et al., 2003). Indeed, our results are most consistent with the hypothesis that Fyn promotes the pathogenic effects of small nonfibrillar $A \beta$ assemblies (Lambert et al., 1998), although interactions with alternative hAPP metabolites have not yet been excluded. Studies are needed to determine whether therapeutic manipulations of Fyn or related pathways could protect the aging brain against pathogenic $\mathrm{A} \beta$ assemblies and $\mathrm{AD}$-related neurological decline.

\section{References}

Arancio O, Zhang HP, Chen X, Lin C, Trinchese F, Puzzo D, Liu S, Hegde A, Yan SF, Stern A, Luddy JS, Lue LF, Walker DG, Roher A, Buttini M, Mucke L, Li W, Schmidt AM, Kindy M, Hyslop PA, et al. (2004) RAGE potentiates $\mathrm{A} \beta$-induced perturbation of neuronal function in transgenic mice. EMBO J 23:4096-4105.

Atkins CM, Selcher JC, Petraitis JJ, Trzaskos JM, Sweatt JD (1998) The MAPK cascade is required for mammalian associative learning. Nat Neurosci 1:602-609.

Bi X, Gall CM, Zhou J, Lynch G (2002) Uptake and pathogenic effects of amyloid beta peptide 1-42 are enhanced by integrin antagonists and blocked by NMDA receptor antagonists. Neuroscience 112:827-840.

Blum S, Moore AN, Adams F, Dash PK (1999) A mitogen-activated protein kinase cascade in the CA1/CA2 subfield of the dorsal hippocampus is essential for long-term spatial memory. J Neurosci 19:3535-3544.

Chawla MK, Guzowski JF, Ramirez-Amaya V, Lipa P, Hoffman KL, Marriott LK, Worley PF, McNaughton BL, Barnes CA (2005) Sparse, environmentally selective expression of Arc RNA in the upper blade of the rodent fascia dentata by brief spatial experience. Hippocampus 15:579-586.

Chin J, Palop JJ, Yu G-Q, Kojima N, Masliah E, Mucke L (2004) Fyn kinase modulates synaptotoxicity, but not aberrant sprouting, in human amyloid precursor protein transgenic mice. J Neurosci 24:4692-4697.

Cummings JL, Kaufer D (1996) Neuropsychiatric aspects of Alzheimer's disease: the cholinergic hypothesis revisited. Neurology 47:876-883.

Dawson GR, Tricklebank MD (1995) Use of the elevated plus maze in the search for novel anxiolytic agents. Trends Pharmacol Sci 16:33-36.

Dineley KT, Westerman M, Bui D, Bell K, Ashe KH, Sweatt JD (2001) $\beta$-Amyloid activates the mitogen-activated protein kinase cascade via hippocampal $\alpha 7$ nicotinic acetylcholine receptors: in vitro and in vivo mechanisms related to Alzheimer's disease. J Neurosci 21:4125-4133.

Eddleston MP, Mucke L (1993) Molecular profile of reactive astrocytesimplications for their role in neurologic disease. Neuroscience 54:15-36.

Eng LF, Ghirnikar RS, Lee YL (2000) Glial fibrillary acidic protein: GFAPthirty-one years (1969-2000). Neurochem Res 25:1439-1451.

Fenster CP, Whitworth TL, Sheffield EB, Quick MW, Lester RA (1999) Upregulation of surface $\alpha 4 \beta 2$ nicotinic receptors is initiated by receptor desensitization after chronic exposure to nicotine. J Neurosci 19:4804-4814.

Gotz J, Streffer J, David D, Schild A, Hoerndli F, Pennanen L, Kurosinski P, Chen F (2004) Transgenic animal models of Alzheimer's disease and related disorders: histopathology, behavior and therapy. Mol Psychiatry 9:664-683.

Grace EA, Rabiner CA, Busciglio J (2002) Characterization of neuronal dystrophy induced by fibrillar amyloid $\beta$ : implications for Alzheimer's disease. Neuroscience 114:265-273.

Guzowski JF (2002) Insights into immediate-early gene function in hippocampal memory consolidation using antisense oligonucleotide and fluorescent imaging approaches. Hippocampus 12:86-104.

Guzowski JF, McNaughton BL, Barnes CA, Worley PF (1999) Environment-specific expression of the immediate-early gene Arc in hippocampal neuronal ensembles. Nat Neurosci 2:1120-1124.

Guzowski JF, Lyford GL, Stevenson GD, Houston FP, McGaugh JL, Worley PF, Barnes CA (2000) Inhibition of activity-dependent arc protein expression in the rat hippocampus impairs the maintenance of long-term potentiation and the consolidation of long-term memory. J Neurosci 20:3993-4001.

He J, Yamada K, Nabeshima T (2002) A role of Fos expression in the CA3 region of the hippocampus in spatial memory formation in rats. Neuropsychopharmacology 26:259-268.

Higgins GA, Jacobsen H (2003) Transgenic mouse models of Alzheimer's disease: phenotype and application. Behav Pharmacol 14:419-438.

Ho G, Drego R, Hakimian E, Hashimoto M, Tong G, Thal L, Masliah E (2004) Involvement of Fyn and MAP kinase signaling in synaptic loss in Alzheimer's disease. Soc Neurosci Abstr 30:218.5.

Holcomb LA, Gordon MN, Jantzen P, Hsiao K, Duff K, Morgan D (1999) Behavioral changes in transgenic mice expressing both amyloid precursor protein and presenilin-1 mutations: lack of association with amyloid deposits. Behav Genet 29:177-185.

Hsia A, Masliah E, McConlogue L, Yu G, Tatsuno G, Hu K, Kholodenko D, Malenka RC, Nicoll RA, Mucke L (1999) Plaque-independent disruption of neural circuits in Alzheimer's disease mouse models. Proc Natl Acad Sci USA 96:3228-3233.

Kamboh MI (2004) Molecular genetics of late-onset Alzheimer's disease. Ann Hum Genet 68:381-404.

Kelleher III RJ, Govindarajan A, Tonegawa S (2004) Translational regulatory mechanisms in persistent forms of synaptic plasticity. Neuron 44:59-73.

Kennedy MB (1997) The postsynaptic density at glutamatergic synapses. Trends Neurosci 20:264-268.

Klein WL, Krafft GA, Finch CE (2001) Targeting small A $\beta$ oligomers: the solution to an Alzheimer's disease conundrum. Trends Neurosci 24:219-224.

Kobayashi DT, Chen KS (2005) Behavioral phenotypes of amyloid-based genetically modified mouse models of Alzheimer's disease. Genes Brain Behav 4:173-196.

Kojima N, Wang J, Mansuy IM, Grant SGN, Mayford M, Kandel ER (1997) Rescuing impairment of long-term potentiation in fyn-deficient mice by introducing Fyn transgene. Proc Natl Acad Sci USA 94:4761-4765.

Kojima N, Ishibashi H, Obata K, Kandel ER (1998) Higher seizure susceptibility and enhanced tyrosine phosphorylation on $N$-methyl-D-aspartate receptor subunit 2B in fyn transgenic mice. Learn Mem 5:429-445.

Kremerskothen J, Wendholt D, Teber I, Barnekow A (2002) Insulininduced expression of the activity-regulated cytoskeleton-associated gene (ARC) in human neuroblastoma cells requires p21(ras), mitogenactivated protein kinase/extracellular regulated kinase and src tyrosine kinases but is protein kinase C-independent. Neurosci Lett 321:153-156. Lambert MP, Barlow AK, Chromy BA, Edwards C, Freed R, Liosatos M, Morgan TE, Rozovsky I, Trommer B, Viola KL, Wals P, Zhang C, Finch CE, Krafft GA, Klein WL (1998) Diffusible, nonfibrillar ligands derived 
from $\mathrm{A} \beta_{1-42}$ are potent central nervous system neurotoxins. Proc Natl Acad Sci USA 95:6448-6453.

Lee KW, Lee SH, Kim H, Song JS, Yang SD, Paik SG, Han PL (2004) Progressive cognitive impairment and anxiety induction in the absence of plaque deposition in C57BL/6 inbred mice expressing transgenic amyloid precursor protein. J Neurosci Res 76:572-580.

Lipp HP, Wolfer DP (1998) Genetically modified mice and cognition. Curr Opin Neurobiol 8:272-280.

Lyford GL, Yamagata K, Kaufmann WE, Barnes CA, Sanders LK, Copeland NG, Gilbert DJ, Jenkins NA, Lanahan AA, Worley PF (1995) Arc, a growth factor and activity-regulated gene, encodes a novel cytoskeletonassociated protein that is enriched in neuronal dendrites. Neuron 14:433-445.

Mayeux R (2003) Epidemiology of neurodegeneration. Annu Rev Neurosci 26:81-104.

Molinari S, Battini R, Ferrari S, Pozzi L, Killcross AS, Robbins TW, Jouvenceau A, Billard J-M, Dutar P, Lamour Y, Baker WA, Cox H, Emson PC (1996) Deficits in memory and hippocampal long-term potentiation in mice with reduced calbindin $\mathrm{D}_{28 \mathrm{~K}}$ expression. Proc Natl Acad Sci USA 93:8028-8033.

Mucke L, Abraham CR, Ruppe MD, Rockenstein EM, Toggas SM, Alford M, Masliah E (1995) Protection against HIV-1 gp120-induced brain damage by neuronal expression of human amyloid precursor protein. J Exp Med 181:1551-1556.

Mucke L, Masliah E, Yu G-Q, Mallory M, Rockenstein EM, Tatsuno G, Hu K, Kholodenko D, Johnson-Wood K, McConlogue L (2000) High-level neuronal expression of $\mathrm{A} \beta_{1-42}$ in wild-type human amyloid protein precursor transgenic mice: synaptotoxicity without plaque formation. J Neurosci 20:4050-4058.

Nguyen TH, Liu J, Lombroso PJ (2002) Striatal enriched phosphatase 61 dephosphorylates Fyn at phosphotyrosine 420. J Biol Chem 277: 24274-24279.

Palop JJ, Jones B, Kekonius L, Chin J, Yu G-Q, Raber J, Masliah E, Mucke L (2003) Neuronal depletion of calcium-dependent proteins in the dentate gyrus is tightly linked to Alzheimer's disease-related cognitive deficits. Proc Natl Acad Sci USA 100:9572-9577.

Palop JJ, Chin J, Bien-Ly N, Massaro C, Yeung BZ, Yu G-Q, Mucke L (2005) Vulnerability of dentate granule cells to disruption of Arc expression in human amyloid precursor protein transgenic mice. J Neurosci 25:9686-9693.

Pelkey KA, Askalan R, Paul S, Kalia LV, Nguyen TH, Pitcher GM, Salter MW, Lombroso PJ (2002) Tyrosine phosphatase STEP is a tonic brake on induction of long-term potentiation. Neuron 34:127-138.

Pinaud R, Penner MR, Robertson HA, Currie RW (2001) Upregulation of the immediate early gene arc in the brains of rats exposed to environmental enrichment: Implications for molecular plasticity. Mol Brain Res 91:50-56.

Raber J, Akana SF, Bhatnagar S, Dallman MF, Wong D, Mucke L (2000) Hypothalamic-pituitary-adrenal function in $A p o e^{-1-}$ mice: possible role in behavioral and metabolic alterations. J Neurosci 20:2064-2071.

Rockenstein EM, McConlogue L, Tan H, Gordon M, Power M, Masliah E, Mucke L (1995) Levels and alternative splicing of amyloid $\beta$ protein precursor (APP) transcripts in brains of transgenic mice and humans with Alzheimer's disease. J Biol Chem 270:28257-28267.

Roskoski Jr R (2004) Src protein-tyrosine kinase structure and regulation. Biochem Biophys Res Commun 324:1155-1164.

Sabo S, Lambert MP, Kessey K, Wade W, Krafft G, Klein WL (1995) Interaction of $\beta$-amyloid peptides with integrins in a human nerve cell line. Neurosci Lett 184:25-28.

Salter MW, Kalia LV (2004) Src kinases: a hub for NMDA receptor regulation. Nat Rev Neurosci 5:317-328.

Santuccione A, Sytnyk V, Leshchyns'ka I, Schachner M (2005) Prion pro- tein recruits its neuronal receptor NCAM to lipid rafts to activate p59 fyn and to enhance neurite outgrowth. J Cell Biol 169:341-354.

Shirazi SK, Wood JG (1993) The protein tyrosine kinase, fyn, in Alzheimer's disease pathology. NeuroReport 4:435-437.

Snyder EM, Nong Y, Almeida CG, Paul S, Moran T, Choi EY, Nairn AC, Salter MW, Lombroso PJ, Gouras GK, Greengard P (2005) Regulation of NMDA receptor trafficking by amyloid- $\beta$. Nat Neurosci 8:1051-1058.

Steward O, Wallace CS, Lyford GL, Worley PF (1998) Synaptic activation causes the mRNA for the IEG Arc to localize selectively near activated postsynaptic sites on dendrites. Neuron 21:741-751.

Sweatt JD (2004) Mitogen-activated protein kinases in synaptic plasticity and memory. Curr Opin Neurobiol 14:311-317.

Tanzi R, Bertram L (2005) Twenty years of the Alzheimer's disease amyloid hypothesis: a genetic perspective. Cell 120:545-555.

Terry RD, Masliah E, Salmon DP, Butters N, DeTeresa R, Hill R, Hansen LA, Katzman R (1991) Physical basis of cognitive alterations in Alzheimer's disease: synapse loss is the major correlate of cognitive impairment. Ann Neurol 30:572-580.

Thomas SM, Brugge JS (1997) Cellular functions regulated by src family kinases. Cell Dev Biol 13:513-609.

Toggas SM, Masliah E, Rockenstein EM, Rall GF, Abraham CR, Mucke L (1994) Central nervous system damage produced by expression of the HIV-1 coat protein gp120 in transgenic mice. Nature 367:188-193.

Turner PR, O'Connor K, Tate WP, Abraham WC (2003) Roles of amyloid precursor protein and its fragments in regulating neural activity, plasticity and memory. Prog Neurobiol 70:1-32.

Verdier Y, Penke B (2004) Binding sites of amyloid beta-peptide in cell plasma membrane and implications for Alzheimer's disease. Curr Protein Pept Sci 5:19-31.

Wall PM, Messier C (2001) Methodological and conceptual issues in the use of the elevated plus-maze as a psychological measurement instrument of animal anxiety-like behavior. Neurosci Biobehav Rev 25:275-286.

Walsh DM, Selkoe DJ (2004) Deciphering the molecular basis of memory failure in Alzheimer's disease. Neuron 44:181-193.

Waltereit R, Dammermann B, Wulff P, Scafidi J, Staubli U, Kauselmann G, Bundman M, Kuhl D (2001) Arg3.1/Arc mRNA induction by $\mathrm{Ca}^{2+}$ and cAMP requires protein kinase $\mathrm{A}$ and mitogen-activated protein kinase/ extracellular regulated kinase activation. J Neurosci 21:5484-5493.

Westerman MA, Cooper-Blacketer D, Mariash A, Kotilinek L, Kawarabayashi T, Younkin LH, Carlson GA, Younkin SG, Ashe KH (2002) The relationship between $\mathrm{A} \beta$ and memory in the Tg2576 mouse model of Alzheimer's disease. J Neurosci 22:1858-1867.

Williamson R, Scales T, Clark BR, Gibb G, Reynolds CH, Kellie S, Bird IN, Varndell IM, Sheppard PW, Everall I, Anderton BH (2002) Rapid tyrosine phosphorylation of neuronal proteins including tau and focal adhesion kinase in response to amyloid- $\beta$ peptide exposure: Involvement of Src family protein kinases. J Neurosci 22:10-20.

Wolfer DP, Stagljar-Bozicevic M, Errington ML, Lipp HP (1998) Spatial memory and learning in transgenic mice: fact or artifact? News Physiol Sci 13:118-123.

Yaar M, Zhai S, Pilch PF, Doyle SM, Eisenhauer PB, Fine RE, Gilchrest BA (1997) Binding of beta-amyloid to the p75 neurotrophin receptor induces apoptosis—a possible mechanism for Alzheimer's disease. J Clin Invest 100:2333-2340.

Yan SD, Chen X, Fu J, Chen M, Zhu HJ, Roher A, Slattery T, Zhao L, Nagashima M, Morser J, Migheli A, Nawroth P, Stern D, Schmidt AM (1996) RAGE and amyloid- $\beta$ peptide neurotoxicity in Alzheimer's disease. Nature 382:685-691.

Ying SW, Futter M, Rosenblum K, Webber MJ, Hunt SP, Bliss TV, Bramham CR (2002) Brain-derived neurotrophic factor induces long-term potentiation in intact adult hippocampus: requirement for ERK activation coupled to CREB and upregulation of ArC synthesis. J Neurosci 22:15321540. 